GEORG CANTOR 



\section{GEORG CANTOR \\ His Mathematics and Philosophy \\ of the Infinite}

Joseph Warren Dauben

PRINCETON UNIVERSITY PRESS

PRINCETON, NEW JERSEY 
Published by Princeton University Press, 41 William Street, Princeton, New Jersey 08540

Copyright (C) 1979 by the President and Fellows of Harvard College

\section{All Rights Reserved}

First Princeton Paperback printing, 1990

Reprinted by arrangement with the author and Harvard University Press

Library of Congress Cataloging-in-Publication Data Dauben, Joseph Warren, 1944

Georg Cantor: his mathematics and philosophy of the infinite/ Joseph Warren Dauben.

p. $\mathrm{cm}$.

Reprint. Originally published: Cambridge, Mass.: Harvard University Press, 1979.

Includes bibliographical references and index.

ISBN 0-691-08583-8 (cloth)

ISBN 0-691-02447-2 (paper)

1. Set theory-History. 2. Numbers, Transfinite-History.

3. Cantor, Georg, 1845-1918. 4. Infinite. I. Title.

QA248.D27 1990

$511.3^{\prime} 22^{\prime} 09-\mathrm{dc} 20 \quad 90-8579$

Princeton University Press books are printed on acid-free paper, and meet the guidelines for permanence and durability of the Committee on Production Guidelines for Book Longevity of the Council on Library Resources

$\begin{array}{lll}10 & 9 & 8\end{array}$

Printed in the United States of America 
FOR MY PARENTS,

FOR ELAINE,

AND FOR DAVID 
